DOI No: http://dx.doi.org/10.29228/Joh.49847

Authenticity process is conducted by

Makale Türü: Araştırma makalesi

Geliş Tarihi: 08-03-2021

Kabul Tarihi: 16-06-2021

On-line Yayın: 30-06-2021

Article Type: Research article Submitted: 08-03-2021

Accepted: 16-06-2021

Published Online: 30-06-2021

Atıf Bilgisi / Reference Information

Et, S. Z. \& Gömleksiz M. N. (2021). Analysis of Argumentation Application in Terms of Learner Experiences. Journal of History School, 52, 1785-1805.

\title{
ANALYSIS OF ARGUMENTATION APPLICATION IN TERMS OF LEARNER EXPERIENCES ${ }^{1}$
}

\author{
Sümeyra Zeynep ET ${ }^{2}$ \& Mehmet Nuri GÖMLEKSİZ ${ }^{3}$
}

\begin{abstract}
Problem-solving, inquiry, decision-making, and supporting these decisions on solid grounds are among the skills expected from today's individuals. Experiences in inquirybased learning environments are crucial for individuals to fulfill these requirements. In this context, the research aims to determine the opinions and experiences of 24 science teacher candidates who participated in the Argumentation-Based Inquiry (ABI) approach practices, one of the inquiry activities. Research data were collected through student journals. The research aimed to determine the feelings and thoughts of teacher candidates regarding argumentation practices with student journals. Research data were analyzed using the content analysis method. Some of the results obtained in the study are as follows. Teacher candidates stated that the ABI approach made the course entertaining and interesting. They stated that they can actively participate in the process so that the knowledge they have gained regarding the answers to the questions they seek becomes more meaningful. Further, teacher candidates have often expressed in the journals that

\footnotetext{
${ }^{1}$ This study is a part of the doctoral thesis submitted to Frrat University Institute of Educational Sciences. Article writing author influence rate: 1 st author: 50\%, 2nd author: 50\%. Ethics committee approval for this article was obtained at Firat University with the number 208735.

2 Researrch Assistant, Kastamonu University, Education Faculty, Department of Education Programs and Instruction, szeynepet@kastamonu.edu.tr, Orcid: 0000-0002-0176-4788

3 Professor, Mehmet Nuri Gömleksiz, Furat University, Education Faculty, Department of Education Programs and Instruction, ngomleksiz@yahoo.com, Orcid: 0000-0002-8268-0163
} 


\section{Sümeyra Zeynep ET \& Mehmet Nuri GÖMLEKSİZ}

they have an important awareness to be able to make claims in this process and to support their claims with evidence, i.e., to defend their ideas.

Keywords: Argumentation-based inquiry approach, Inquiry, Argumentation, Science teacher candidates

\section{Argümantasyon Uygulamalarının Öğrenen Deneyimleri Açısından İncelenmesi}

\section{$\ddot{\mathbf{O z}}$}

Problem çözme, araştırma-sorgulama yapma, karar verme ve bu kararları gerekçelerle destekleyebilme günümüz bireylerinden beklenen yeterlilikler arasında yer almaktadır. Bireylerin kendilerinden beklenen bu yeterlilikleri yerine getirebilmelerinde araştırmasorgulamaya dayalı öğrenme ortamlarında edindikleri deneyimler çok önemlidir. $\mathrm{Bu}$ bağlamda araştırmanın amacını araştırma-sorgulama aktivitelerinden biri olan argümantasyon tabanlı bilim öğrenme yaklaşımı (ATBÖ) uygulamalarına katılan 24 fen bilgisi öğretmen adayının bu sürece ilişkin görüş ve deneyimlerinin belirlenmesi oluşturmaktadır. Araştırma verileri öğrenci günlükleri aracılığıyla toplanmıştır. Öğrenci günlükleriyle öğretmen adaylarının argümatasyon uygulamalarına ilişkin duygu ve düşüncelerini neler olduğunun belirlenmesi amaçlanmıştır. Araştırma verileri, içerik analizi yöntemi kullanılarak analiz edilmiştir. Araştırmada elde edilen sonuçlardan bazıları şu şekildedir: öğretmen adayları ATBÖ yaklaşımının dersi eğlenceli ve ilgi çekici hale getirdiğini ifade etmişlerdir. Sürece aktif katılabildiklerini böylelikle cevap aradıkları soruların yanıtlarına ilişkin edindikleri bilgilerin kendileri için daha anlamlı hale geldiğini belirtmişleridir. Ayrıca öğretmen adayları bu süreçte iddia oluşturabilme, iddialarını delillerle destekleme yani fikirlerini savunabilme yönünde önemli bir farkındalık yaşadıklarını tutmuş oldukları günlüklerde sık sık dile getirmişlerdir.

Anahtar Kelimeler: Argümantasyon, Araştırma-sorgulama, Argümantasyon temelli bilim öğrenme yaklaşımı, Fen bilgisi öğretmen adayları.

\section{INTRODUCTION}

In recent years, inquiry-based learning has become important in science education worldwide and has become one of the key objectives of science education reforms in many countries, such as the UK, Japan, Australia, and Taiwan (Li et al., 2020, p. 2). With the inclusion of inquiry-based learning in science programs and increase in its importance in science education, one of the challenges has been to improve interrogation teaching, especially open inquiry (Zion, Schwartz, Rimerman Shmueli \& Adler, 2018, p. 2). A misconception about this situation is that inquiry is experienced by individuals not only as an 
Analysis of Argumentation Application in Terms of Learner Experiences

exploration experiment but also as explanation and argument formation (MoNE, 2013 , p. 3). One of the inquiry-based practices to prevent this misleading in science teaching is the arguments (Sampson, Grooms \& Walker, 2011, p. 218; Kabataş Memiş \& Çakan Akkaş, 2016, p.18; Aktaş \& Doğan, 2018, p. 779) being considered necessary to be included in science teaching.

Potential contributions of including argumentation, which is considered to be an integral part of science in science classes, are expressed by Jiménez Aleixandre and Erduran (2007, p.3) as science literacy, determining epistemological criteria and developing critical thinking and reasoning skills. There is a broad consensus that the argumentation should be structured in science education when considering the contributions involved in the argument (Lazarou, Erduran \& Sutherland, 2017, p. 57) and that the argument skills are important (Quintana \& Correnti, 2018, p. 1).

ABI approach, which includes inquiry-based applications that allow individuals to follow a path that includes the "question-claim-evidence" process when conducting interrogations (Kara, Yılmaz \& Kingır, 2020, p. 1255), has been one of the approaches used in science teaching in recent years. ABI is an approach based on the foundations of the constructivist learning theory that covers activities such as reading and writing of languages (Aslan \& Tekin, 2015, p. 74), considered an important element in terms of enabling the scientific argumentation and exploration of meanings, originally named Science Writing Heuristic (Keys, Hand, Prain \& Collins, 1999, p. 1065). The approach that was first translated into Turkish (Günel, Kabataş Memiş, \& Büyükkasap, 2010, p. 51) began to be expressed as "Argumentation-based Inquiry" (ABI) approach, which was thought to meet the concept better in the following years (Kingir, Geban, \& Günel, 2012, p. 428).). The ABI is an approach that provides a framework for teachers to help their students gain the questioning skills in science courses through the negotiation process (Cavagnetto, Hand \& Norten Meier, 2011, p. 195) and to increase their top cognitive knowledge of laboratory work (Kingir, 2011, p. 44).

The ABI, enables a deeper understanding of big ideas with science content, allowing students to create and test questions on one subject, support their claims with evidence, and compare their own opinions with others' (Akkus, Günel \& Hand, 2007, p. 1746). At the same time, ABI includes the use of epistemological tools, speaking and writing, in different frameworks including individuals, small groups, and the whole class (Cavagnetto et al., 2011, p. 428) while engaging in inquiry activities (Chen, Hand \& Park, 2016, p. 284). From a practical point of view, the $\mathrm{ABI}$ is a series of activities that will guide both teachers and students in thinking and writing (Hand et al., 2007, p. 131). Regarding this series of activities, 
the templates of Hand and Keys (1999, p. 28) expressing what teachers and students should do during the $\mathrm{ABI}$ process during the laboratory activities are as follows.

\section{Table1}

ABI teacher template

(1) Eliciting previous knowledge through concept maps

(2) Devising and conducting pre-laboratory activities using informal writing, observation, brainstorming, and questioning techniques

(3) Participation in laboratory activities

(4) I. Negotiation Phase - Devising and conducting individual writing activities within laboratory activities (e.g. writing a journal)

(5) II. Negotiation phase - Sharing and comparing the interpretations of data from observations in small groups (e.g. creating drafts in groups)

(6) III. Negotiation Phase - Comparing ideas with those in books or other sources (e.g. taking group notes to answer initial questions)

(7) IV. Negotiation Phase - Conducting individual reflection and writing activities (e.g. preparing a presentation such as a report or a poster for the people to be informed)

(8) Discovering what is learned at the end of instruction

The teacher template includes a range of activities recommended to teachers to enable students to discuss meaningful thinking, writing, and do laboratory work (Kıngır, 2011, p. 45). The student template is shown in Table 2.

\section{Table 2}

ABI student template

1. Initial Thoughts - What are my questions?

2. Tests - What did I do?

3. Observations - What did I see?

4. Claims - What can I claim?

5. Evidence - How did I get it? Why am I making these claims?

6. Reading - How are my thoughts compared to other thoughts?

7. Reflection - How did my opinions change?

The student template allows students to configure scientific knowledge during laboratory applications (Şahin, 2018, p. 112) and make their evaluation in the scientific inquiry process (Nam, Choi \& Hand, 2010, p. 1113) that helps them write laboratory reports effectively (Yaman, 2018, p. 424). Thus, students can use the most useful features of ABI in framing their questions, entering into discussions with the peer group, and developing conceptual ties (Hand et al., 2007, p. 148). These negotiations provide an opportunity for students to collaborate in sharing information and better understand the content (Van Opstal 
\& Daubenmire, 2015, p. 1092). Further, during these dialogues, individuals are expected not only to develop arguments that are about a claim, evidence, and reasoning but also to engage in critical discourse in which they try to convince each other about the validity of their arguments (Aydeniz \& Dogan, 2016, p. 112).

When the relevant literature was examined, the ABI approach was identified as having a positive impact on students' academic achievement (Kabataş Memiş, 2011, p. 96), conceptual understanding (Cronje, Murray, Rohlinger \& Wellnitz, 2013, p. 2718), and critical thinking skills (Sönmez, 2017, p. 122; Stephenson \& Sadler McKnight, 2016, p. 72). In addition to all these contributions of the ABI approach, it is also seen as an effective tool for individuals to be scientifically literate, because it provides an opportunity for the configuration of field knowledge (Kabataş Memiş 2014, p. 414; Yeşildağ Hasançebi \& Günel, 2013, p. 1058).

Based on all this information, it has been seen that the ABI approach has positive effects on learning outcomes (Cronje et al., 2013, p. 2718; Kabataş Memiş 2014, p. 414; Yeşildağ Hasançebi \& Günel, 2013, p. 1058). Therefore, the presence of individuals who can make assessments of these issues in different aspects is considered important for today's societies, in addition to having information about the ABI. Moreover, it is important for candidate teachers who experience the $\mathrm{ABI}$-based learning environment to experience these issues and share their opinions on those experiences. In this context, research conducted to improve and enrich the $\mathrm{ABI}$ experience of teacher candidates is considered necessary. However, the feelings and thoughts of individuals in the process of ABI applications play a key role in the continuity of these applications. Therefore, the main purpose of this study is to reveal the experiences of science teacher candidates based on their feelings and thoughts about ABI.

\section{METHOD}

The research aims to reveal the opinions and experiences of the science teacher candidates participating in the ABI applications. The research is designed as a case study. A case study is defined as the in-depth study of a relatively limited phenomenon to illuminate the characteristics of situations many researchers want to reveal by working with larger audiences (Gerring, 2014, p. 341). In this context, the method of case study, which allows a more in-depth understanding and interpretation of the problem subject to the research, has been preferred. 


\section{Research Context}

It is thought that it will be helpful to be able to understand the environment in which the research is conducted to limit the research results to different studies and to understand how the results of the research can be applied in different environments. The research was conducted with students in the $3^{\text {rd }}$ and $4^{\text {th }}$ year of science studying at the Faculty of Education of a state university in Turkey in the Department of Elementary Science Education. The Primary Science Teaching Bachelor Program has been among the undergraduate programs that train teachers for primary education within the scope of the restructuring process of the Faculty of Education in Turkey. In this undergraduate program, there are courses with different content determined by the Council of Higher Education (YÖK), which is responsible for education and other activities in higher education institutions in Turkey. Candidate teachers take mainly theoretical science courses for the first two years. In the following years, they take more practical courses, such as laboratory applications, teaching methods, and school experience. The nature of the science in which the research is conducted and the history of science are included in a course in this program. The scope of this course is science, understanding the nature of science, teaching the nature of science, scientific knowledge, scientific method, establishing the relationship of science with science, technology, society, and the environment. In this context, the course on the nature of science and the history of science is an important course in the undergraduate program to give teacher candidates a valid and holistic perspective of science. The Nature of Science and Science History course is a course offered in the $6^{\text {th }}$ semester of the science teaching undergraduate program for $3^{\text {rd }}$ - and $2^{\text {nd }}$ year students with an average of 3.00 and above and $4^{\text {th }}$-year students who took the course in previous semesters but did not succeed or did not acquire this course because their credit was not enough.

\section{Participants}

The participants of the study are $163^{\text {rd }}$-year and $84^{\text {th }}$-year students who took the Nature of Science and History of Science course, offered as a compulsory course in the spring semester of 2017-2018 in the Science Teaching Department of a State University in Turkey.

\section{Data Acquisition Tool}

Data for the study were obtained through student journals written weekly after ABI applications. In this context, the journal contained the question "What do you think of the lesson performed today?" and was answered by the teacher 
Analysis of Argumentation Application in Terms of Learner Experiences

candidates after each lesson. In this way, the application process is intended to be revealed from the point of view of the students.

\section{Application Process}

To implement the ABI approach under the teaching design on which it is based, the relevant literature was scanned before determining the topics on which the activities will be based and the topic "Solutions" was chosen, because it is one of the most important topics for the science discipline, and there are widespread misconceptions around it (Demirbaş et al.,2011; Ebenezer, 2001; Papageorgiou \& Sakka, 2000; Valanides 2000; Uzuntiryaki \& Geban, 2005). Applications were not intended to be limited to the discipline of Chemistry, so the topic of "Cell" was chosen as another subject of practice. The reason why applications related to the Physics discipline are not included is that the development of inquiry-based activities is very difficult and the application time only allowed the "Solutions" and "Cell" issues to be planned within three-week processes to form a whole. To demonstrate how the process works in the learning environment created according to the ABI approach, the preparatory stage, "a mysterious event" activity, was carried out with the whole class. After the script text was distributed to each student in the class, the candidate teachers were asked to form groups of 4-5 and make claims based on the text about the death of $\mathrm{Mr}$. Star in the script. In this way, teachers who have ideas about the process are also asked to answer questions, such as "What is the claim?" and "What is the evidence?," and think about the characteristics of quality claims and evidence. Weekly information-sharing about the course was done by creating a virtual classroom through an app called Google Classroom and allowing all the teacher candidates who took the course to join the group. In this virtual classroom environment, announcements and materials related to the course were added, and teacher candidates were prepared accordingly. Further, the teacher candidates were prepared for the course owing to the weekly sharing of the questions they would investigate before the lessons. Applications were conducted in the laboratories of the concerned university.

\section{Analysis of Data}

In the analysis of the data, far beyond simple word counts, content analysis was used, which revealed trends and patterns and is a reliable method of coding as well as classification of data (Stemler, 2000). 


\section{Sümeyra Zeynep ET \& Mehmet Nuri GÖMLEKSİZ}

\section{FINDINGS}

Here, the results of the analysis of the journals held weekly by the teacher candidates within the scope of the research are given. The daily analysis of the solubility-dissolution event is given in Table 3.

\section{Table 3}

Science teacher candidates's (STC) opinions on solubility activity

\begin{tabular}{ll}
\hline What do you think about the lesson held today? & f \\
\hline Was entertaining & 7 \\
Provided the opportunity to try claims & 6 \\
Was interesting & 6 \\
Helpful in finding answers to questions & 5 \\
Was efficient & 5 \\
Ensured the ability to experiment & 4 \\
Ensured permanent learning & 3 \\
Ensured active participation & 2 \\
Provide a scientific perspective & 2 \\
Was relevant to everyday life & 1 \\
Ensured the development of a concept & 1 \\
Provided an opportunity to discuss & 1 \\
\hline
\end{tabular}

Among these categories, the course being "entertaining," "interesting," and it "providing the opportunity to try claims" were the most repeated ones.

Teacher Candidate: "Before we came to the lesson, we conducted several experiments on the questions we found about solution and resolution. During the experiment process and at the end, we had an idea of the authenticity of the claims we had made by observing whether the data overlapped. It was a lesson that we were very curious about and enjoyed."

Teacher Candidate: "Today, we were novices, because we had the opportunity to test our questions for the first time. We had always been given gradually explained experiments, and we tried them, but this time, we tried it voluntarily; our freedom caused our curiosity, interest, and motivation to increase, and it was self-confidence that we saw that we had achieved at the end of the lesson. We were new to it, there was a problem with our questions, and we couldn't be scientific when we were measuring. For example, we tried to measure the salt with a spoon but then corrected our mistakes and did not repeat them. I think we will do better in the next lesson."

Teacher Candidate: "Today, it was surprising that we experienced our claims and evidence, especially after we found questions and tried them. Trying 
Analysis of Argumentation Application in Terms of Learner Experiences

to prove our claims by providing evidence has made learning more permanent. I think it makes me see what a scientist will follow."

Prospective teachers stated that the people who conducted the experiments aroused a sense of curiosity in them, and this made the course interesting. Active participation was another advantage in the learning experience.

The findings from the journal analysis of factors affecting solubility are presented in Table 4.

\section{Table 4}

STC's opinions on the activity of factors affecting solubility

\begin{tabular}{ll}
\hline What do you think about the lesson held today? & f \\
\hline Was entertaining & 6 \\
Ensured answers to questions & 6 \\
Provided evidence & 4 \\
Taught the relationship between claims and evidence & 4 \\
Ensured the ability to conduct an experiment & 4 \\
Aided observe & 3 \\
Ensured permanent learning & 2 \\
Was intriguing & 2 \\
Was efficient & 2 \\
Ensured concretization & 1 \\
Provided awareness & 1 \\
Was difficult & 1 \\
\hline
\end{tabular}

The third activity of the experimental group in which the ABI approach was applied was aimed at factors affecting solubility. The opinions of teacher candidates under the "Ensured answers to questions" and "was entertaining" categories were the most frequently repeated opinions:

Teacher Candidate: "The experiment we conducted today was experimenting with topics that most of us often know about but are often confused about. However, no matter how much we know about it, it gives me pleasure to conduct these experiments. Measuring the temperature of the water with the thermometer and dealing with experiment instruments is quite fun. That's why I liked the lesson. It was a very fun lesson."

Teacher Candidate: "We conducted three experiments in our lesson today. Before we started our experiments, we took advantage of our previous knowledge. We have increased our observation skills."

Teacher Candidate: "I think the lesson we had today was a productive lesson in consolidating the two weeks. I think it is good for proving concrete questions that we know abstractly." 
Teacher candidates have indicated that they can make observations and support their claims by presenting evidence by designing their experiments with their groupmates to find answers to the questions they have prepared for factors affecting solubility. While the dissolution rate is another activity, the findings of this activity are presented as follows.

\section{Table 5}

STC's opinions on the activity of factors affecting dissolution rate

\begin{tabular}{lc}
\hline What do you think about the lesson held today? & f \\
\hline Was entertaining & 9 \\
Ensured answers to questions & 6 \\
Provided an opportunity to discuss & 6 \\
Ensured learning by doing-experiencing & 4 \\
Was efficient & 4 \\
Ensured meaningful, permanent learning & 3 \\
Ensured active participation & 2 \\
Ensured the ability to use imagination/creativity & 2 \\
Provided the ability to create quality questions & 1 \\
\hline \multicolumn{2}{c}{ It is possible to say that the thoughts of teachers about the course that took } \\
place on the factors affecting the rate of dissolution are most often collected under \\
the category of "entertainment."
\end{tabular}

Teacher Candidate: "Teaching the subject through discussions was a good lesson in terms of how everyone thought differently and used creativity and imagination in science."

Teacher Candidate: "To me, the lesson was fun and interesting again. Because it was an active lesson, we do, learn, argue, and defend ourselves. I also think that learning by living and doing is positive in terms of the permanence of what we have learned."

Teacher Candidate: "I think it is a knowledge-filled and fun lesson in which we try to investigate and learn about the questions we have in mind, situations we know or do not know about correctly, and discuss the consequences."

Active participation in the process of experimentation and discussion has led the teacher candidates to consider the lesson to be fun. A teacher candidate stated that they can use creativity and imagination in the process.

Journal questions about cell model activity were analyzed and the resulting categories are included. The findings obtained are given as follows. 
Table 6

STC's Opinions on Cell Model Activity

\begin{tabular}{ll}
\hline What do you think about the lesson held today? & f \\
\hline Provided an opportunity to discuss & 5 \\
Aided in supporting claims with experiments & 4 \\
Ensured the ability to learn new information & 3 \\
Ensured consolidation & 3 \\
Was entertaining & 2 \\
Was efficient & 2 \\
Ensured permanent learning & 2 \\
Ensured clarity & 2 \\
Ensured active participation & 2 \\
Created awareness of shortcomings & 2 \\
Made you think like a scientist & 1 \\
\hline
\end{tabular}

As a result of analyzing the teacher candidate opinions of the course created with the cell model axis, it was observed that the opinions were grouped under 11 categories.

Teacher Candidate: "At the end of the lesson today, we saw our deficiencies in the cell subject. We had discussions with our group members, and the incorrect information we had was identified."

Teacher Candidate: "It provided the embodiment of known information. It was both a fun and instructive lesson. We have created a group of plant cells. During the cell-making phase, we discussed how to make the cell."

Teacher Candidate: "Our lesson was very enjoyable. Other than that, it made me realize my shortcomings. We had discussions with our band friends during class."

Owing to the discussions carried out for the event based on model making using playdough for plants and animal cells, teacher candidates mentioned that they could identify their areas lacking knowledge on the subject.

"Plant and Animal Cell" was another activity carried out. The findings of this activity are presented in Table 7. 
Table 7

STC's opinions on plant and animal cell activity

\begin{tabular}{lc}
\hline What do you think about the lesson held today? & f \\
\hline Enabled observation & 9 \\
Ensured answers to questions & 4 \\
Ensured inference & 4 \\
Provided the opportunity to try claims & 4 \\
Was entertaining & 2 \\
Aided in establishing relationships with everyday life & 2 \\
Was not effective & 2 \\
\hline \multicolumn{2}{c}{ After the plant and animal cell activity, "enabled observation" from the } \\
categories created based on the analysis of teacher candidates' answers was the \\
most common one. Some of the opinions of teachers about this situation are as \\
follows:
\end{tabular}

Teacher Candidate: "We had the opportunity to examine plant and animal cells under a microscope, and we saw that the plant and animal cells were different."

Teacher Candidate: "By viewing plant and animal cells, we observed the differences between them. We saw that they are different. This refreshed our knowledge."

Teacher Candidate: "The lesson we had today was very clear, fluent, understandable, and entertaining. Learning was realized by doing."

The testing of questions prepared by groups for plant and animal cells mainly using microscopes was associated with observation by prospective teachers in both groups. On the contrary, some teacher candidates stated that experiments are useful in terms of inference.

The results of the content analysis of the findings of substance transition in the cell, which was carried out as a seventh-week activity, are given under this heading. The findings obtained are given as follows.

\section{Table 8}

STC's opinions on the activity of substance transition in cell

\begin{tabular}{ll}
\hline What do you think about the lesson held today? & f \\
\hline Ensured answers to questions & 7 \\
Ensured observation & 5 \\
Was efficient & 4 \\
Enabled making an inference & 2 \\
Did not experience a change & 1 \\
Ensured the ability to defend ideas & 1 \\
Ensured the ability to use imagination/creativity & 1 \\
\hline
\end{tabular}


Analysis of Argumentation Application in Terms of Learner Experiences

"Ensured answers to questions" has been the category most commonly expressed by teacher candidates. Some of the participant opinions on this situation are as follows:

Teacher Candidate: "As a result of observations in today's lesson, we learned that we can make an inference. It was useful for us to learn about it. Before this lesson, I didn't know that the inferences depended on observations."

Teacher Candidate: "I think it is a useful lesson in terms of making observations when performing experiments and making an inference in line with the observations. It also allowed me to see imagination and creativity come into practice at the planning stage of experiments."

Teacher Candidate: "We conducted two experiments in today's lesson again. Before conducting experiments in the lab, we prepared our questions. We prepared claims to prove the questions we prepared as a result of the experiments and made observations to support these claims. In the classroom environment, we discussed our experiments with friends and looked at the harmony of our claims and findings."

Teacher candidates expressed that they had the opportunity to answer the questions they prepared after the course. Their experience of providing justifications supporting the claims or learning to raise awareness about presenting evidence to other groups while defending their claims is stated as another advantage.

The Einstein Relativity Theory activity was the last event in the process. The findings of this activity are presented in Table 9.

\section{Table 9}

$\underline{\text { STC's opinions on the activity of the relativity theory }}$

\begin{tabular}{ll}
\hline What do you think about the lesson held today? & f \\
\hline Was efficient & 6 \\
Provided an opportunity to discuss & 4 \\
Experienced an inability to prepare questions & 2 \\
Was entertaining & 1 \\
Ensured consolidation & 1 \\
Enabled providing evidence & 1 \\
\hline
\end{tabular}

Teacher Candidate: "Today's lesson was very productive for me. I realized there was a lot of information that I had wrong, and I learned the correct version." 
Teacher Candidate: "Today's lesson was one that revealed the differences between theory and the law. It was good to learn the difference between these two concepts."

The course on the Einstein Relativity Theory, which was the last activity of the application process, provided an opportunity for teacher candidates to discuss the theory and law of the scientific knowledge that they had expressed doubt about during the discussions. At the end of the process, teacher candidates who changed their ideas about law and theory and thought they had obtained accurate information expressed that the course was productive for them.

\section{CONCLUSION and DISCUSSION}

When the journals were examined, it was found that teacher candidates stated that ABI practices provided them the opportunity to ensure questioning, defend their ideas, and test the questions they were curious about. This is closely related to the fact that $\mathrm{ABI}$ is an approach that takes the student to actively engage in the process and conduct research in the laboratory (Kabataş Memiş, 2014, p. 402). This has resulted in meaningful and permanent learning concepts, because teachers have found the opportunity to investigate the curious aspects of a topic, just like scientists, with other members in the group. Thus, individuals have gained positive experiences regarding many situations, such as observation, measurement, experimentation, recording of data, and making inferences that are evaluated within the scope of scientific process skills. A similar result was revealed in the work of Deveci \& Talk (2020) with teachers of science. Teachers have indicated that being involved in the ABI process has a positive impact on their scientific process skills.

Driver et al., (2000, p. 302) mentioned the benefits of including scientific discussions in science classes. One of these benefits is that the ability of individuals to research can be developed through discussions. During ABI activities, teacher candidates are asked to overcome situations, such as creating questions that represent a scientifically acceptable problem, developing hypotheses to these questions, designing an experiment for their hypothesis, and creating a claim as a result of all this. It can be said that the discussions of the candidate teachers throughout the process and the situations they face regarding the steps that involve conducting scientific research lead to positive changes in their research abilities. In this process, individuals encounter many situations, such as revealing a research problem, collecting data and designing experiments related to this problem, evaluating alternative ideas and interpretations, having 
scientific discussions with groupmates, making valid and meaningful statements about their ideas and observations, and making assessments about how their knowledge has changed. Thus, students develop not only their knowledge about science subjects but also their research skills (Kaya \& K1lıç, 2008, p. 99) during discussion activities. Opinions such as the opportunity to test the claims and questions expressed by the teacher candidates, observation, experimentation, making inferences, understanding the difference between observation and inference, hypothesis, willingness to conduct research, thinking like a scientist, creativity, and the importance of imagination support the positive changes in teacher candidates in different steps of scientific research.

When the opinions of the teacher candidates about the process are evaluated holistically, it can be said that ABI practices have positive effects on the points of individuals being able to question, form claims, present evidence to support their claims, learn new information, make discussions, and make observations and inferences. These results were actually important in showing that teacher candidates consider the potential contributions of ABI applications in the acquisition of scientific process skills. As teacher candidates were able to actively participate in the process and design course environments to answer their questions, their motivation levels for the course increased, and they found the lessons fun and efficient at the same time.

Given their positive contributions to learning outputs, ABI applications can be said to be very important for individuals to experience the research and query process. For this reason, it should be ensured that prospective teachers encounter more learning environments based on ABI practices. In this way, today's learners, who are the teachers of tomorrow, will understand that inquiry in their professional lives is not only about the exploration experiment process but also about the ability to include explanation and argument. Thus, both teachers and learning environments will be the biggest supporters of permanent and meaningful learning.

\section{REFERENCES}

Akkus, R., Gunel, M., \& Hand, B. (2007). Comparing an inquiry-based approach known as the Science writing heuristic to traditional science teaching practices: are there differences?. International Journal of Science Education, 29(14), 1745-1765. https://doi.org/10.1080/09500690601075 629 
Aktaş, T., \& Doğan, Ö. K. (2018). The effect of argument driven inquiry model on academic performances and argumentative attitudes of 7th grade students. Mersin University Journal of the Faculty of Education, 14(2), 778-798. https://doi.org/10.17860/mersinefd.342569

Aslan, S., \& Tekin, N. (2015). Reporting laboratory applications in argumentbased science inquiry report format effects on conceptual understanding and using modal representation. Erzincan University Journal of Education Faculty, 17(1), 73-97. https://doi.org/10.17556/jef.08506

Aydeniz, M., \& Dogan, A. (2016). Exploring the impact of argumentation on preservice science teachers' conceptual understanding of chemical equilibrium. Chemistry Education Research and Practice, 17(1), 111-119. 10.1039/C5RP00170F

Cavagnetto, A. R. (2010). Argument to foster scientific literacy: A review of argument interventions in K-12 science contexts. Review of Educational Research, 80(3), 336-371. https://doi.org/10.3102/0034654310376953

Cavagnetto, A. R., Hand, B., \& Norten Meier, L. (2011). Negotiating the inquiry question: A comparison of whole class and small group strategies in grade five science classrooms. Research in Science Education, 41, 193-209. 10.1007/s11165-009-9152-y

Chen, Y. C., Hand, B., \& Park, S. (2016). Examining elementary students' development of oral and written argumentation practices through argument-based inquiry. Science \& Education, 25, 277-320. DOI 10.1007/s11191-016-9811-0

Cronje, R., Murray, K., Rohlinger, S., \& Wellnitz, T. (2013). Using the science writing heuristic to improve undergraduate writing in Biology. International Journal of Science Education, 35(16), 2718-2731. https://doi.org/10.1080/09500693.2011.628344

Demirbaş, M., Tanrıverdi, G., Altınışık, D., \& Şahintürk, Y. (2011). The impact of conceptual change texts on the elimination of misconceptions of science teacher candidates about the subject of solutions. Sakarya University Journal of Education, 1(2), 52-69.

Deveci, İ., \& Konuş, F. Z. (2020). Knowledge and experience of science teachers with regard to argumentation-based science learning, Bolu Abant Izzet Baysal University Journal of Education Faculty, 20(1), 454-475. 
Analysis of Argumentation Application in Terms of Learner Experiences

Driver, R., Newton, P., \& Osborne, J. (2000). Establishing the norms of scientific argumentation in Classrooms. Science Education, 84(3), 287-312. https://doi.org/10.1002/(SICI)1098-237X(200005)84:3<287::AID-SCE1> 3.0.CO;2-A

Ebenezer, J. V. (2001). A hypermedia environment to explore and negotiate students' conceptions: animation of the solution process of table salt. Journal of Science Education and Technology, 10(1), 73-92.

Gerring, J. (2004). What is a case study and what is it good for?. American Political Science Review, 98(2), 341-354.

Günel, M., Kabataş Memiş, E. \& Büyükkasap, E. (2010). Yaparak yazarak bilim öğrenimi-yybö yaklaşımının ilköğretim öğrencilerinin Fen akademik başarısına ve fen ve teknoloji dersine yönelik tutumuna etkisi. Eğitim ve Bilim, 35(155), 49-62.

Hand, B., Wallace, C. W., \& Yang, E. M. (2007). Using a science writing heuristic to enhance learning outcomes from laboratory activities in seventh-grade science: Quantitative and qualitative aspects. International Journal of Science Education, 26(2), 131-149. https://doi.org/10.1080/ 0950069032000070252

Hand, B., \& Keys, C. W. (1999). Inquiry investigation. The Science Teacher, 66(4), 27-29.

Jiménez Aleixandre, M. P., \& Erduran, S. (2007). Argumentation in science education: An overview. In S. Erduran and M. P. Jimenez-Aleixandre (Eds.). Argumentation in Science Education. Dordrecht (pp. 3-27).

Kabataş Memiş, E. (2014). Elementary students' ideas about on implementation of argumentation based science learning approach. Kastamonu Education Journal, 22(2), 401-418.

Kabataş Memiş, E., \& Çakan Akkaş, B. N. (2016). Inquiry based application in preschool education: an example for the subject of density. Online Science Education Journal, 1(1),17-29.

Kara, S., Y1lmaz, S., \& King1r, S.(2020). The effect of argumentation based science learning approach on the academic achievement and argumentation quality levels of primary students. Kastamonu Education Journal, 28(3), 1253-1267. https://doi.org/10.24106/kefdergi.3785 
Kaya, O. N., \& Kılıç, Z. (2008). Argumentative discourse for the effective teaching of science. Ahi Evran University Kırşehir Journal of Education Faculty, 9(3), 89-100.

Keys, C. W., Hand, B., Prain, V., \& Collins, S. (1999). Using the science writing heuristic as a tool for learning from laboratory investigations in secondary science. Journal of Research in Science Teaching, 36(10), 1065-1084. https://doi.org/10.1002/(SICI)1098-2736(199912)36:10<1065::AID-TEA 2>3.0.CO;2-I

Kıngir, S. (2011). Using The Science Writing Heuristic Approach to Promote Student Understanding in Chemical Changes and Mixtures. Doctoral dissertation, Middle East Technical University.

Kingir, S., Geban, O. \& Gunel, M. (2012). How does the science writing heuristic approach affect students' performances of different academic achievement levels? A case for high school chemistry. Chemistry Education Research and Practice, 13(4), 428-436.

Lazarou, D., Erduran, S., \& Sutherland, R. (2017). Argumentation in science education as an evolving concept: Following the object of activity. Learning, Culture and Social Interaction, 14, 51-66. https://doi.org/10. 1016/j.lcsi.2017.05.003

Li, X., Tan, Z., Shen, J., Hu, W., Chen, Y., \& Wang, J. (2020). Analysis of five junior high school physics textbooks used in china for representations of nature of science. Research in Science Education, 50, 833-844. https://doi.org/10.1007/s11165-018-9713-z

Ministry of National Education [MoNE] (2013). Fen Bilimleri Dersi Öğretim Programi, 3. 4. 5. 6. 7. ve 8. Siniflar) [Science curriculum, $3 \mathrm{rd}$, 4th, 5th, 6th, 7th, and 8th grades]. https://ridvansoydemir.wordpress.com/2013fen-bilimleri-ogretim-programi/, Access date: 10.12.2020

Nam, J., Choi, A., \& Hand, B. (2011). Implementation of the science writing heuristic (swh) approach in 8th grade science classrooms. International Journal of Science and Mathematics Education, 9, 1111-1133.

Quintana, R., \& Correnti, R. (2018). The right to argue: Teaching and assessing everyday argumentation skills. Journal of Further and Higher Education, 1-19. https://doi.org/10.1080/0309877X.2018.1450967 
Analysis of Argumentation Application in Terms of Learner Experiences

Papageorgiou, G., \& Sakka, D. (2000). Prımary school teachers'views on fundamental chemical concepts. Chemistry Education Research and Practice, 1(2), 237-247. doi: 10.1039/A9RP90025J

Sampson, V., Grooms, J., \& Walker, J. P. (2011). Argument-driven inquiry as a way to help students learn how to participate in scientific argumentation and craft written arguments: An Exploratory study. Science Education, 95(2), 217-257. https://doi.org/10.1002/sce.20421

Sönmez, E. (2017). Impacts of Argumentation-Based Science Learning Approach on the Science Pre-Service Teachers' Critical Thinking in the General Chemistry Laboratory Course. Doctoral dissertation, Kastamonu University.

Stemler, S. (2000). An overview of content analysis. Practical Assessment, Research, and Evaluation, 7(7), 1-6. https://doi.org/10.7275/z6fm-2e34

Stephenson, N. S., \& Sadler McKnight, N. P. (2016). Developing critical thinking skills using the science writing heuristic in the chemistry laboratory. Chemistry Education Research and Practice, 17(1), 72-79.

Uzuntiryaki, E. \& Geban, Ö. (2005). Effect of conceptual change approach accompanied with concept Mapping on understanding of solution concepts. Instructional Science, 33(4), 311-339.

Valanides, N. (2000). Primary student teachers' understanding of the partıculate nature of matter and its transformations during dissolving. Chemistry Education Research and Practice, 1(2), 249-262.

Van Opstal, M. T., \& Daubenmire, P. L. (2015). Extending students' practice of metacognitive regulation skills with the science writing heuristic. International Journal of Science Education, 37(7), 1089-1112. https://doi.org/10.1080/09500693.2015.1019385

Yaman, F. (2018). Effects of the science writing heuristic approach on the quality of prospective science teachers' argumentative writing and their understanding of scientific argumentation. International Journal of Science and Mathematics Education, 16, 421-442. doi: 10.1007/s10763016-9788-9

Yeşildağ Hasançebi, F., \& Günel, M. (2013). Effects of argumentation based inquiry approach on disadvantaged students' science achivement. Elementary Education Online,12(4), 1056-1073 
Zion, M., Schwartz, R. S., Rimerman Shmueli, E., \& Adler, I. (2020). Supporting teachers' understanding of nature of science and inquiry through personal experience and perception of inquiry as a dynamic process. Research in Science Education, 50, 1281-1304. https://doi.org/10.1007/s11165-0189732-9

\section{EXTENDED ABSTRACT}

Purpose: The purpose of this study is to reveal the experiences of science teacher candidates based on their feelings and thoughts about Argumentation-Based Inquiry (ABI).

Method: The research aims to reveal the opinions and experiences of the science teacher candidates participating in the ABI applications. The research is designed as a case study. The participants of the study are $163^{\text {rd }}$-year and $84^{\text {th }}$-year students who took the Nature of Science and History of Science course. Data for the study were obtained through student journals written weekly after ABI applications. In this context, the journal contained the question "What do you think of the lesson performed today?" and was answered by the teacher candidates. In the analysis of the data, far beyond simple word counts, content analysis was used.

Findings: The results of the analysis of the journals held weekly by the teacher candidates within the scope of the research are given. Pre-service teachers stated that they found the lesson fun and interesting. Active participation in the process of experimentation and discussion has led the teacher candidates to consider the lesson to be fun. In addition to pre-service teachers stated that the people who conducted the experiments aroused a sense of curiosity in them, and this made the course interesting.

Result and Argument: ABI approach, which includes inquiry-based applications that allow individuals to follow a path that includes the "questionclaim-evidence" process when conducting interrogations (Kara, Y1lmaz \& Kingir, 2020), has been one of the approaches used in science teaching in recent years. the presence of individuals who can make assessments of these issues in different aspects is considered important for today's societies, in addition to having information about the ABI. Therefore, the main purpose of this study is to reveal the experiences of science teacher candidates based on their feelings and thoughts about ABI. When the opinions of the teacher candidates about the process are evaluated holistically, it can be said that ABI practices have positive effects on the points of individuals being able to question, form claims, present evidence to support their claims, learn new information, make discussions, and 
Analysis of Argumentation Application in Terms of Learner Experiences

make observations and inferences. These results were actually important in showing that teacher candidates consider the potential contributions of ABI applications in the acquisition of scientific process skills. As teacher candidates were able to actively participate in the process and design course environments to answer their questions, their motivation levels for the course increased, and they found the lessons fun and efficient at the same time.

Given their positive contributions to learning outputs, ABI applications can be said to be very important for individuals to experience the research and query process. For this reason, it should be ensured that prospective teachers encounter more learning environments based on ABI practices. 